\title{
Good living of communities and sustainability of the hydropower business: mapping an operational framework for benefit sharing
}

\author{
Indira Jiménez-Inchima ${ }^{*} \mathbb{D}$, Jorge-Andrés Polanco and Manuela Escobar-Sierra
}

\begin{abstract}
The negative impact of hydropower companies is cushioned frequently through compensation that is proportional neither to the needs of communities nor to the energy business. Considering the dependence of hydropower on the environment, it is unclear how the good living of communities can be combined with the long-term sustainability of power companies. Therefore, the purpose of this study was to establish a benefit sharing scheme between hydropower companies and local communities. We conducted a systematic literature review using a sequential mixedmethod approach. In the first stage, we performed a quantitative bibliometric analysis, and its results, described in Model 1.0, were the basis of the second stage. Consequently, in the second stage, we conducted a content analysis of 40 documents to enrich the previous version of the model in Framework 2.0. After completing both the methodological stages, we prepared a theoretical operational framework for benefit sharing based on collaborative governance that assigned different specific weights for companies and local communities. Equal benefit sharing is the result of an adaptive process that depends on (1) the performance of companies, (2) the level of empowerment of communities and (3) the state's capacity to intervene in setting rules of engagement that help reduce power asymmetries between companies and the society.
\end{abstract}

Keywords: Benefit sharing, Corporate sustainability, Good living, Collaborative governance, Literature review

\section{Background}

Over the past decades, companies have come under the spotlight in relation to the debate on sustainability because they have been held accountable for several adverse impacts affecting the environment and society [1]. In this context, companies need to conduct a comprehensive assessment of their management practices. Corporate sustainability and its measurement gained importance because of the need to coordinate financial performance, environmental quality and society's

*Correspondence: indira.jime@gmail.com

Faculty of Economics and Administrative Sciences, University of Medellin,

Carrera 87 No. 30-65, 050026 Medellín, Colombia well-being [2]. This relation between businesses, society and environment stems from the re-significance of concepts, such as quality of life and well-being, based on the notion of good living $[3,4]$. Good living requires the critical appraisal of development and responding comprehensively to social and economic imperatives in harmony with nature [5]. It moves beyond the notion of well-being based on income and material assets [6].

Corporate sustainability and communities' good living are combined through benefit sharing, understood as 'a set of operating practices and policies that enhance a company's competitiveness and also help improve the economic and social conditions of the communities original author(s) and the source, provide a link to the Creative Commons licence, and indicate if changes were made. The images or other third party material in this article are included in the article's Creative Commons licence, unless indicated otherwise in a credit line to the material. If material is not included in the article's Creative Commons licence and your intended use is not permitted by statutory regulation or exceeds the permitted use, you will need to obtain permission directly from the copyright holder. To view a copy of this licence, visit http://creativecommons.org/licenses/by/4.0/. The Creative Commons Public Domain Dedication waiver (http://creativeco mmons.org/publicdomain/zero/1.0/) applies to the data made available in this article, unless otherwise stated in a credit line to the data. 
in which it is implemented' [7]. Benefit sharing entails interaction between society and corporate performance; it offers a broader view of business that addresses both companies' productivity and society's needs [8].

The hydropower sector is not an exception. In response to the needs created by world population growth, climate change and economic growth, the search for new unconventional sources of renewable energy (e.g. solar and wind, among others) has gained momentum, and the use of renewable sources of conventional energy (hydropower) has consolidated [9]. Hydropower has been the leading source of renewable energy across the world and is thriving [10]. However, the construction and operation of hydropower plants has an economic, environmental and social cost for local communities [9]. In fact, social, mental and economic changes and pressures affect communities, hindering their lifestyle and scope for good living, consequence of territorial reconfiguration imposed by the hydroelectric companies [11].

Benefit sharing is a new term in the hydropower sector that has been adopted by the International Hydropower Association (IHA) [12]. This concept encompasses interpretations, objectives and practices that are still not clearly understood. The term is defined as a governance method under which extractive companies share directly with affected communities a portion of the benefits from their operations, thus moving beyond the compensationbased approach [13]. The academic and scientific contributions in this area have increased over the past decade and mainly address the strengths and weaknesses of benefit sharing mechanisms [14]. They have also focused on obstacles in finding a common framework that balances companies' competitiveness with the well-being of the communities settled in the territories where such entities operate because of the asymmetrical nature of direct negotiations between companies and communities [11].

According to UNEP [15], benefit sharing is part of the impact assessment strategies of hydropower plants. Impact assessment considers the participation of interest groups, which has given important results in the evaluation of social impact and is a structural basis of the shared benefit sought with the use of this technology [16, 17]. Environmental management plans are increasingly consolidated as tools [18] that are integrated with the social aspect in such a way that they contribute to compliance with the sector's development policies and the regulations of each country [15].

From this standpoint, benefit sharing poses major challenges; further, there are multiple perspectives on the conditions under which benefit sharing could serve best as an approach [14]. From the scientific literature, several studies have shown from real experiences of the hydroelectric sector important results [19-21], which have allowed them to raise significant contributions towards the optimisation of the mechanisms of distribution of the shared benefit. Because of the scarcity of literature that focuses explicitly on this issue [22], authors like Duarte et al. [11] and Pulice et al. [23] have expressed the need for further exploration to respond to the numerous crucial questions about ways to ensure the equal distribution of the benefits and costs of hydropower energy. Dongnan et al. [24] posit that the implications of long-term benefit sharing should be examined. Furthermore, Pulice et al. [23] recommend analysing benefit sharing from a strategic standpoint to understand ways to foster economic growth and social development in a coordinated manner. Moran et al. [9] agree with this perspective and suggest that sustainable solutions should be developed to enhance the benefits of energy businesses and the communities living around dams.

Integrating business sustainability with communities' good living by sharing the benefits gained by businesses seems to be an unfulfilled purpose. Because of the asymmetric nature of the negotiations between businesses and society, the issue of how benefits can be distributed evenly in the long term is still unclear and needs to be addressed in research. Consequently, our research question emerges: how could a benefit sharing scheme between hydropower companies and local communities be established?

Such a knowledge gap with regard to corporate sustainability, good living and benefit sharing exists in the hydropower sector. The purpose of this study was to establish a benefit sharing scheme between hydropower companies and local communities. To this end, we carried out a systematic literature review using sequential mixed method. In the first stage, we performed a quantitative bibliometric analysis. We described its results in Model 1.0, and used it as the basis for the second stage, which involved a qualitative content analysis. Then, in the second stage, we review 40 documents to enrich the preliminary version of Model 1.0 through a more in-depth analysis that is shown in Framework 2.0. This means that after completing the quantitative and qualitative methodological stages, a theoretical operational framework assigning different specific weights to companies and society in obtaining the shared benefits was formulated on the basis of collaborative governance. Finally, three case studies are presented which, in different regional contexts, allow us to extend the theoretical results found.

The text is organised as follows. The theoretical background is illustrated in "Theoretical framework" section, and the research method is described in "Materials and methods" section. "Results" section contains the results obtained through the mixed sequence method. "Discussion" section presents the key findings of the literature 
review. Finally, "Conclusions" section includes the conclusions and limitations of the study, as well as the scope for further research.

\section{Theoretical framework}

Economic development fuelled by the industrial revolution boosted business productivity, but also resulted in major environmental and social problems [25]. As a response, in the 1980s, the concept of sustainable development was introduced, understood as 'development that meets the needs of the present without compromising the ability of future generations to meet their own needs' [26]. Corporate sustainability arises under this approach as a way for companies to face demands and risks, offering a guiding framework to articulate practices aimed at sustainable development [27].

At present there is no single or homogeneous definition of the term corporate sustainability [2]. In this study, corporate sustainability is considered as comprising a company's present and future performance [2]. Present performance is understood as the minimisation of economic, social and environmental impacts, involving factors such as social and environmental well-being that guide sustainable development and companies' financial performance. Future performance is related to the issue of governance pertaining to companies' political and ethical positions, considering relationships between players within a territory and in the business environment [2].

This definition of corporate sustainability is grounded on three theoretical approaches: institutional theory $[28,29]$, resource- and capability-based $[30,31]$ and stakeholder [32]. Institutional theory [28, 29] addresses institutional environments focused on social norms. Organisations are bound to meet both market and government requirements to ensure legitimacy and efficiency $[33,34]$.

The resource- and capability-based theory relies on the heterogeneity of companies' resources and internal capabilities as the fundamental base of its strategy and the main determinants of its profitability [31, 35]. This theory is characterised by the relation between companies' strategies and capabilities, hence the importance of its internal processes in which knowledge (i.e. intangible resource) and administrative processes (i.e. tangible resources) are key to creating value [30,31]. Finally, with regard to the stakeholder theory [36, 37], Freeman defines stakeholders as individuals or groups that can affect companies' performance. Thus, companies are considered not as independent from their stakeholders but rather as closely related to customers, suppliers, communities and other groups. Because of the relation between companies and stakeholders, the former adopts sustainability strategies [38].

Corporate sustainability assumes that companies' main goal is not merely to gain profits and that the relations with the environment and the community play a major role in building and developing an improved environment [39]. As companies' involvement in different areas of communities' daily life and, therefore, in its wellbeing, was recognised, the concept of good living gained importance.

Human well-being is a concept that poses major difficulties in interpretation [40]. Over time, several theories have tried to gain a deeper understanding, encompassing a holistic and integrated view from the standpoint of human basic needs, oriented to the intangible values of existence [41]. Max-Neef [42], in his theory of needs, states that needs are few, finite and classifiable and that what changes is the way in which these needs are satisfied. From this perspective, quality of life depends on an individual's capability to satisfy their basic human needs. Alguacil [43] based on his theory of complexity and adopting a multidimensional approach, raises the need to move beyond quantitative variables to introduce qualitative factors involving dimensions such as environmental quality, well-being and cultural identity. In the context of critical development studies, the notion of 'good living' was born recently, based on the worldview of the Andean peoples. The concept is an approximate translation of the phrases sumak kawsay in Quechua and suma qamaña in Aymara [44].

In this study, good living is considered the possibility of another way of life through a series of social, economic and environmental rights and guarantees [45]. This notion adopts a holistic view in which material goods are not the only determining factors and there are 'other values at stake: knowledge, social and cultural recognition, ethics and spiritual codes of conduct in the relation between society and nature, human values and a vision of the future, among others' [6] (p. 4).

Good living is examined from Verhulst's perspective [5] as a proposition in response to the problems of collective life and the issue of sustainability. Good living may be understood as a distinctive Latin American path towards global socio-environmental sustainability, as suggested by the Quito Declaration [46]. Thus, good living falls within the scope of the critical development theory, and as stated by Gudynas and Acosta [47, p. 108], 'far from relying solely on business relations, good living aims at dynamic and constructive relations between the market, society and state.'

In the interrelation between economy and society, it is in the context of territory that shared value [7] arises as a proposition for organisations that seek to link corporate 
economic development with societal development. From this standpoint, the business sector is expected to renew its processes and activities considering the social environment in which it operates, without compromising the search for and collection of profits but being aware of the benefits that may be extended to the social arena.

According to Pfitzer et al. [48], companies have been integrating in their business operations a model of delivering social benefits and also generating economic value; in other words, companies understand and assume their responsibility towards society. This concept aims to reaffirm the importance of the relation between societies and companies and ensures that the latter share their benefits with the community and thus create value for both parties rather than just for themselves. In this sense, Porter and Kramer [7] assure that companies can create economic value while also creating social value. It is understood that a company's success and the well-being of the community in which it operates are not mutually exclusive; they should rather be aligned.

From this benefit sharing standpoint, collaborative governance is important specifically because it involves the study of arrangements between companies and societies that are also promoted by state agencies through public policies [49]. At present, other alternatives combining different players such as social and community-based organisations are recognised and managed to create collaborative governance schemes [50]. Emerson et al. [50] notes that collaborative governance is understood as the processes and structures of public-policy decision-making and management that engage people constructively across boundaries of public agencies; levels of government and/or the public, private and civic spheres to carry out a public purpose that could not otherwise be accomplished'.

Benefit sharing can be discussed in theory and also on the basis of facts, especially in the field of water resource management in relation to hydropower plants. The World Bank defines benefit sharing as the systematic efforts made by project proponents to sustainably benefit local communities affected by hydropower investments' [13].

There are different viewpoints with regard to the optimisation of benefit sharing mechanisms between communities, governments and companies, including the negotiation of compensations and risk allocation [51]. Dombrowsky et al. [22] and Wang [13] argue that benefit sharing schemes should move beyond compensation and hence encourage social and economic gains for affected populations that have already been compensated for their losses. Furthermore, Pulice et al. [23], based on the Brazilian experience, concur with Dombrowsky et al. [22], whose research is based in Africa's Great Lakes region, when they assert that monetary compensation as a benefit sharing mechanism is not a key to promoting the development of a region. In this context, there is a debate on the conceptualisation of the methods for distributing benefits, wherein it is argued that there may be different types of strategies from financial compensation to social issue management, including conflict resolution and negotiation management. The benefit sharing approach adopted in this sector changed from one-sided to cooperative actions, thus reaping more benefits [14].

Therefore, benefit sharing is often understood as an integrated approach for impact assessment of hydropower [15]. On the contrary, it is related to monetary compensation policies, such as shared revenues; regional funds; taxes [23] and non-monetary compensation policies, such as restoration of livelihoods, community development, food security [15] and land asset securitisation [52]. Further, it is also related to socio-environmental impact assessment [53] and participatory approaches to impact evaluation [54].

The cooperative actions in the hydropower sector face the same difficulties as water governance in Colombia $[11,55]$. The water governance methods implemented by hydropower plants legitimate the inefficient allocation of this resource, disregarding the perceptions, interests and values of the local communities. This occurs in a context of asymmetric negotiation in which economic appraisals prevail over ecological, social and cultural ones. This is also the case in Central Asia (i.e. Kyrgyzstan, Tajikistan and Uzbekistan). According to Soliev et al. [14], there are still major barriers to governance because of the lack of historical and institutional analysis [14].

There are still several controversies with regard to the conditions under which benefit sharing can best serve as an approach to water resource management [14]. There is an ongoing debate on the importance of benefit sharing management systems that are used as a coordinated strategy across organisations in the search for links between business growth and societal development [56].

Therefore, there is a need to define a comprehensive management framework that includes adaptation processes, legal and formal guidelines and stakeholder engagement [14]. This adaptive management framework may minimise conflicts in negotiations by better understanding the communities' interests and capabilities [14, 57]. Although benefit sharing schemes are fuelled by concerns about social justice, human rights, engagement and empowerment, governance structures and processes need to be better understood to ensure the efficient design of the operational framework [58].

As stated by Jorda et al. [59], there is a need for a proposal that combines increased stakeholder engagement, better understanding of ecosystem functioning, 
awareness of plurality of values and an accurate choice of valuation methods.

\section{Materials and methods}

Recently, numerous changes have occurred in research methodology pertaining to (1) literature reviews [60] due to the bias that is often associated with them and (2) the increased availability of data [61]. Therefore, we decided to apply a mixed-method approach that attends to previous suggestions of some authors [62] and appeals to a methodological triangulation that supports its rigour and significance [63] and follows an approach that has been previously applied by other authors [64]. With this purpose, we decided to first conduct a bibliometric analysis that applies data mining techniques to a large amount of data available in scientific databases [61] and then tried to review more in depth these findings through traditional content analysis [65] in the second stage.

Specifically, the stage 1 consisted of a quantitative bibliometric analysis, which was used as a basis to create the initial conceptual model. The bibliometric analysis encompasses the application of mathematical and statistical methods to books, articles and other means of communication to measure the quantity, performance and some structural indicators that determine the connection between publications, authorities and research areas. Stage 2 used the initial model as basis for the qualitative content analysis of 40 documents filtered from scientific databases according to the Preferred Reporting Items for Systematic Reviews and Meta-Analysis (PRISMA) model [66]. Content analysis was conducted on the basis of the grounded theory methodology [67] to adjust the initial model through theoretical saturation. This saturation was obtained through a systematic coding process using
Atlas.Ti software. Finally, the adjusted model was related to the targeted operational framework. We include below the stages of the systematic literature review.

\section{Quantitative stage}

To gather data in this first stage, we used a search equation determined by five (5) subject classifications, namely, corporation, sustainability, benefit sharing, society and case study. Each subject classification was defined and structured adopting the citation pearl growing strategy [68], as detailed in Fig. 1.

We then chose Scopus (which are the most important multidisciplinary databases in the academic field [69]) as search engines. Next, we used the search equation provided in Table 1 to identify the scientific information contained in article titles, abstracts and/or keywords.

From this search process, we collected 968 documents in Scopus databases between September and October 2019. These documents were then analysed using the free software VOSviewer [70], a tool for visualising bibliometric networks developed by the Centre for Science and Technology Studies (CWTS). This software generated, among others, a knowledge map and a matrix of repetitive words that were used to build the initial conceptual model and the basic codes to perform the content analysis in the second stage.

\section{Qualitative stage}

For this stage, we used the documents contained in Scopus and Web of science databases obtaining 968 in Scopus and 511 in Web of Science, in addition to 5 documents identified through other sources. We specifically used the documents published over the past 9 years in fields other than medicine, in order to obtain the most

\begin{tabular}{|c|c|c|c|c|}
\hline CORPORATION & SUSTAINABILITY & $\begin{array}{l}\text { BENEFIT- } \\
\text { SHARING }\end{array}$ & SOCIETY & CASE OF STUDY \\
\hline Organization & Sustainability & Share benefit & Well - being & Hydropower \\
\hline Firm & Business Ethics & Profit Share & Quality of life & Energy Firm \\
\hline Enterprise & $\begin{array}{c}\text { Societal } \\
\text { responsibility }\end{array}$ & Share concept & Good living & $\begin{array}{c}\text { Energy } \\
\text { Corporation }\end{array}$ \\
\hline \multirow[t]{2}{*}{ Project } & & Distribution profits & Buen Vivir & Dam \\
\hline & & Share Value & Livelihood & Reservoir \\
\hline
\end{tabular}




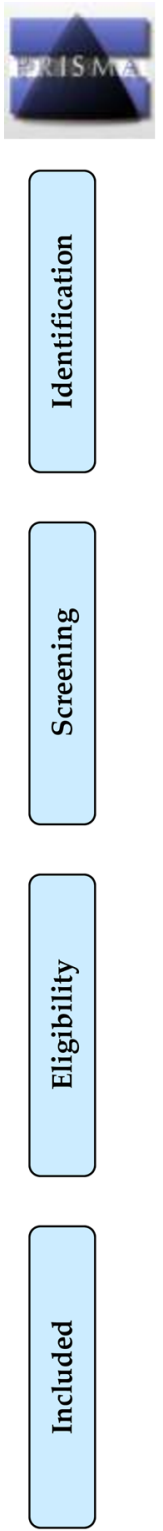

\section{PRISMA 2009 Flow Diagram}

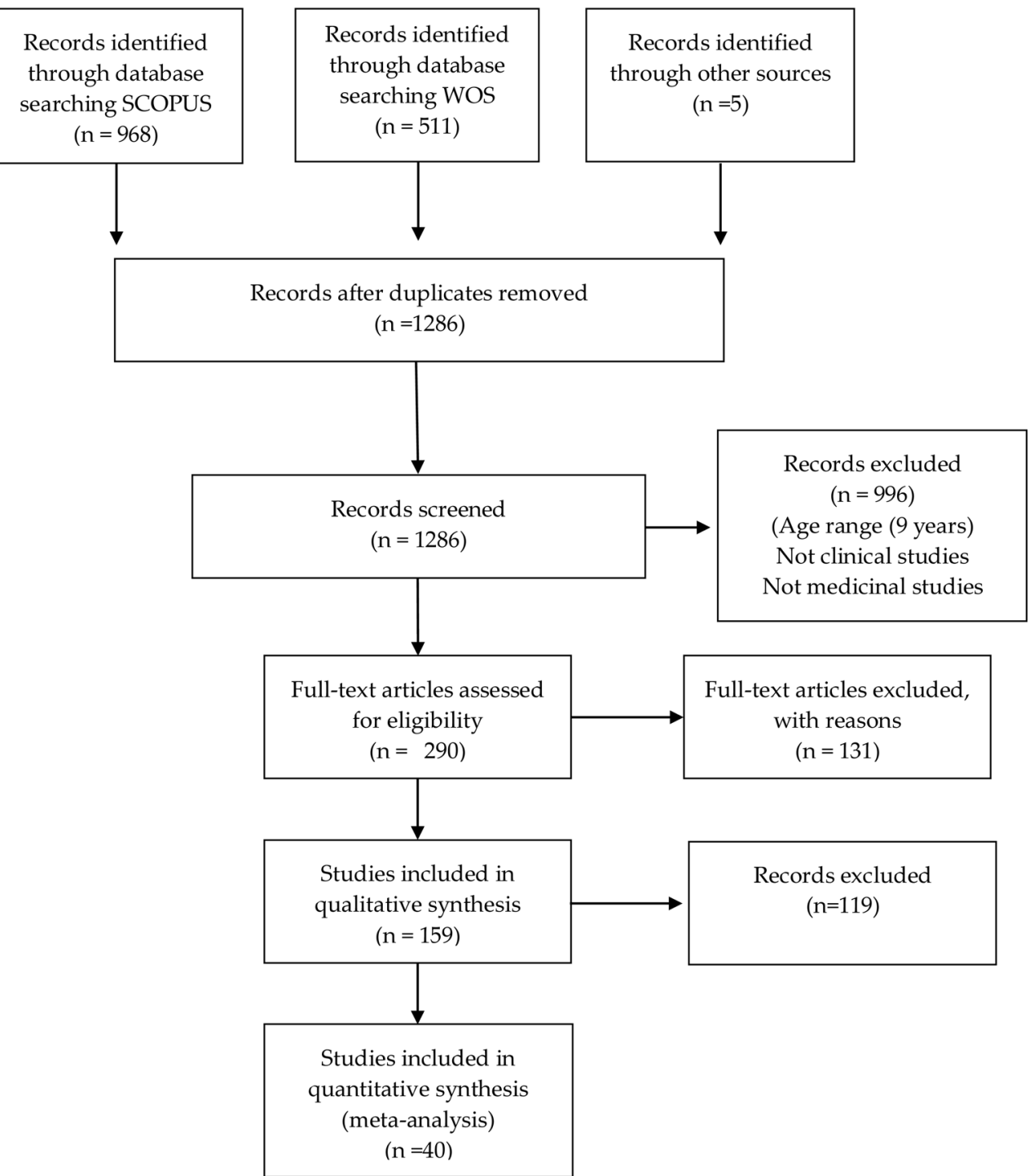

Fig. 2 Preferred Reporting Items for Systematic Review and Meta-Analysis (PRISMA) flowchart for the keywords used in the literature review [66]

recent sources. After eliminating the duplicated documents, we obtained 1286 records. Once we extracted the information contained in these documents, we filtered them following the PRISMA model [66]. This model consists of a flowchart (Fig. 2) that combines the search strategy with the selection of research papersfrom identification to the final selection, resulting in 40 documents.

To analyse the 40 documents selected, we used Atlas. Ti software (Version 7.5.16) to support the data analysis

Table 1 Search equation related to case study

("Corporat*"or "busines*"or "compan*"or "firm"or "organi*"or "enterprise"or "entity*")and("sustainabili*"or "socialresponsibil"or"ethic*"or "businessethi*"or "develop*")and("shar*"or "profit"or "revenue"or "benefit*"or "mutual"or "advantag*"or "distribution"or "value"or "benefit* shar" or "share* benefit*")and("well bein*"or "well-being"or "quality of lif*"or "good liv"or "liv* wel*"or "live happ*"or "live great*"or "buen vivir"or "lifequali*"or "liv*condit*"or "livelihood")and("hydropow*"or "energy*"or "watersh*"or "dam*"or "reservoir"or "hydroel"*) 
process because it facilitates the construction of theories by representing the data in graphical maps, diagrams or hierarchical or relational schemes [71]. This tool also facilitates data analysis and allows for an examination of the relations between concepts, thus building the categories that will embody the targeted operational framework.

For content analysis, we used grounded theory to perform conceptual development because it favours the creation of concepts and clearly defines the procedure for data analysis to facilitate theory construction [67].

First, we built some a priori research categories (Table 2) based on the review of previous research on the topic and results from bibliometric analysis. We defined each category and subcategory based on different theoretical research studies that addressed sustainability $[2,72]$ and governance $[50,73]$ under benefit sharing schemes. We also used notions from the International Hydropower Association Sustainability Assessment Protocol [12], which gathers the proper practices, policies, regulations and guidelines for developing sustainable hydropower projects.

To analyse the information, we performed open, axial and selective coding processes [67]. Open coding involved the analysis of the documents chosen by building analytical categories that were specified on the basis of their properties and dimensions. Then, in axial coding, we linked the categories with the subcategories systematically in relation to a core category to provide accurate explanations on the studied phenomenon. We performed axial coding until we reached theoretical saturation. As explained by Corbin and Strauss [67], this occurs when (a) no new relevant data seem to emerge, (b) the category is well-developed in terms of its properties and dimensions and (c) the relations among categories are well established and validated. Finally, we performed selective coding to integrate and refine categories after they were built and linked to subcategories during axial coding. We also identified emerging codes that contributed to understanding the phenomenon studied, thus creating a theoretical model of the same.

To validate the information and gain a deeper understanding of the reality examined, we cross-referenced the information collected to the theoretical and academic reflections in the area to reduce biases and enhance the understanding of the phenomenon being studied $[71,75]$. This procedure helped minimise biases and cross-check what appeared to be evident and the findings with interpretations about a certain subject of study [76]. Next, we arrived at conclusions that, based on theoretical reflection, allowed us to cross-check, compare, validate, broaden and contextualise the information surveyed to organise the expected operational framework. Lastly, we estimated the frequency of occurrence and co-occurrence of the codes [77]. The former was used to calculate the order of importance of the codes and the latter the potential relations between them. The more frequent the occurrence was, the greater was the importance. This information was useful to estimate the specific weight of the components of the model and their relations.

\section{Results}

Results are presented in two parts. First, we show the quantitative results from the bibliometric technique chosen, from which the preliminary operational framework was created, i.e. Model 1.0. The second part contains the results from the qualitative stage related to the content analysis of the documents chosen from the quantitative research conducted, from which the final operational framework was developed, i.e. Framework 2.0.

\section{Preliminary operational framework}

We carried out a bibliometric analysis of a unified corpus of 968 records of Scopus based on the search results of the equation proposed in the bibliography chosen.

The co-occurrence network or knowledge map of the keywords (see Fig. 3) was designed using VOSviewer software. The size of the nodes and words represents the weight of the nodes: the larger the node, the greater the weight. The distance between the two nodes shows the nature of the relation between the two nodes. A shorter distance reveals a stronger relation. The nodes with the same colour belong to the same group.

In this specific case, the keywords of the publications related to the topic researched are disclosed in four clusters or groups. In addition, using this bibliometric tool, we obtained 10 words with the weight of the top occurrences of the publications found (Table 3) per group or cluster. We found that three clusters (1, 3 and 4) were related to the subject of study, but cluster 2 was made up of health-related words, so we ruled it out.

Upon reviewing the occurrence of the terms, we identified three explicit groups of analysis in the literature: the first group (cluster 1) comprises terms such as 'project', 'production', 'sustainability', 'economy', 'government', 'sector', 'business', 'market', 'investment' and 'sustainable development'. The second group (cluster 3) includes terms such as 'livelihood, 'climate change', 'land', 'conservation,' 'ecosystem, 'stakeholder', 'farmer', 'agriculture', 'natural resource' and 'household'. Finally, the third group (cluster 4) encompasses terms such as 'conflict', 'sense leader', 'actor', 'idea', 'insight', 'good', 'wealth', 'employee' and 'satisfaction'.

Based on these results, we designed our preliminary model-model 1.0 (Fig. 4). This model was built based on the three chosen clusters and the participation of 
Table 2 Pre-established categories

\begin{tabular}{|c|c|c|}
\hline Category & Subcategory & Code \\
\hline \multirow[t]{10}{*}{ Corporation } & \multirow{2}{*}{$\begin{array}{l}\text { Project } \\
\text { Hydropower or hydroelectricity projects refers to the conversion of energy from flow- } \\
\text { ing water into electricity [74] }\end{array}$} & Usual Project \\
\hline & & Share Value project \\
\hline & \multirow{6}{*}{$\begin{array}{l}\text { Sustainability } \\
\text { Corporate activities that proactively seek to contribute to sustainability equilibria, } \\
\text { including the economic, environmental, and social dimensions of today, as well } \\
\text { as their inter-relations within and throughout the time dimension (i.e. the short-, } \\
\text { long-, and longer-term), while addressing the company's systems, i.e. operations } \\
\text { and production, management and strategy, organizational systems, procurement } \\
\text { and marketing, and assessment and communication; as well as with its stakehold- } \\
\text { ers [72] }\end{array}$} & Economic \\
\hline & & Environmental \\
\hline & & Social \\
\hline & & Economic-society \\
\hline & & Economic-environment \\
\hline & & Society-environment \\
\hline & \multirow{2}{*}{$\begin{array}{l}\text { Government } \\
\text { The combination of processes and structures that inform, direct, manage and moni- } \\
\text { tor the activities of the project toward the achievement of its objectives [12] }\end{array}$} & Corporate governance \\
\hline & & External Governance \\
\hline \multirow[t]{16}{*}{ Society } & \multirow{5}{*}{$\begin{array}{l}\text { Livelihood } \\
\text { Refers to the capabilities, assets [stores, resources, claims and access] and activities } \\
\text { required for a means of living [12] }\end{array}$} & Improvement of livelihoods \\
\hline & & Economic displacement \\
\hline & & Measures to address project \\
\hline & & Opportunities for project-affected communities \\
\hline & & Interrelationships \\
\hline & \multirow{2}{*}{$\begin{array}{l}\text { Climate change } \\
\text { Analysis and management of the risks of climate change for the project, and the } \\
\text { project's role in climate change adaptation[12] }\end{array}$} & Environmental and social risks \\
\hline & & Environmental and social opportunities \\
\hline & \multirow{2}{*}{$\begin{array}{l}\text { Land } \\
\text { Analysis of land use change with hydroelectric project }\end{array}$} & Access to Land Use \\
\hline & & Land rehabilitation \\
\hline & \multirow{3}{*}{$\begin{array}{l}\text { Ecosystem } \\
\text { This topic addresses ecosystem values, habitat and specific issues such as threatened } \\
\text { species, reservoir and downstream areas, as well as potential impacts associated } \\
\text { with the operating hydropower facility[12] }\end{array}$} & Biodiversity issues \\
\hline & & Measures to address impacts on biodiversity \\
\hline & & Biodiversity opportunities \\
\hline & \multirow{4}{*}{$\begin{array}{l}\text { Stakeholders } \\
\text { Who are interested in, involved in or affected by the hydropower project and associ- } \\
\text { ated activities [12] }\end{array}$} & Mapping \\
\hline & & Needs \\
\hline & & Negotiation \\
\hline & & Participation \\
\hline \multirow[t]{8}{*}{ Share benefit } & \multirow{3}{*}{$\begin{array}{l}\text { Causes of Conflict } \\
\text { The Corporations are perceived to be responsible for many negative impacts on the } \\
\text { environment and on societies [72] }\end{array}$} & Environmental \\
\hline & & Social \\
\hline & & Economic \\
\hline & \multirow{2}{*}{$\begin{array}{l}\text { Actions/outputs } \\
\text { People and organizations collaborate across boundaries to get something done [50] }\end{array}$} & Non-monetary mechanisms \\
\hline & & Monetary mechanisms \\
\hline & \multirow{3}{*}{$\begin{array}{l}\text { Satisfaction } \\
\text { Collaborative actions or outputs are taken in the hopes of producing desired out- } \\
\text { comes, or results on the ground. These intermediate and end outcomes are essen- } \\
\text { tially alterations in an existing or projected condition that is viewed as undesirable } \\
\text { or in need of change [73] }\end{array}$} & Effectiveness of outcomes \\
\hline & & legitimacy of outcomes \\
\hline & & Adaptation \\
\hline
\end{tabular}

the weights of their components. Cluster 1 obtained the highest participation with respect to total frequencies obtained, with $53 \%$. The participation of cluster 3 and cluster 4 stood at $35 \%$ and $12 \%$, respectively.

Using this model, we made our first approach to the operational framework regarding topics and potential relations. In other words, for example, topics such as investment, businesses and market seem to be related (cluster 1) and more important in the literature than topics such as ecosystems, conservation and agriculture (cluster 2). Furthermore, the latter topics seem to be more important than topics such as actor, satisfaction and conflict (cluster 3). These clusters were used to build the operational framework.

\section{Theoretical model for the operational framework}

This section presents the results obtained in the qualitative stage in three subsections: (1) general considerations, (2) content analysis of the 40 chosen documents and 


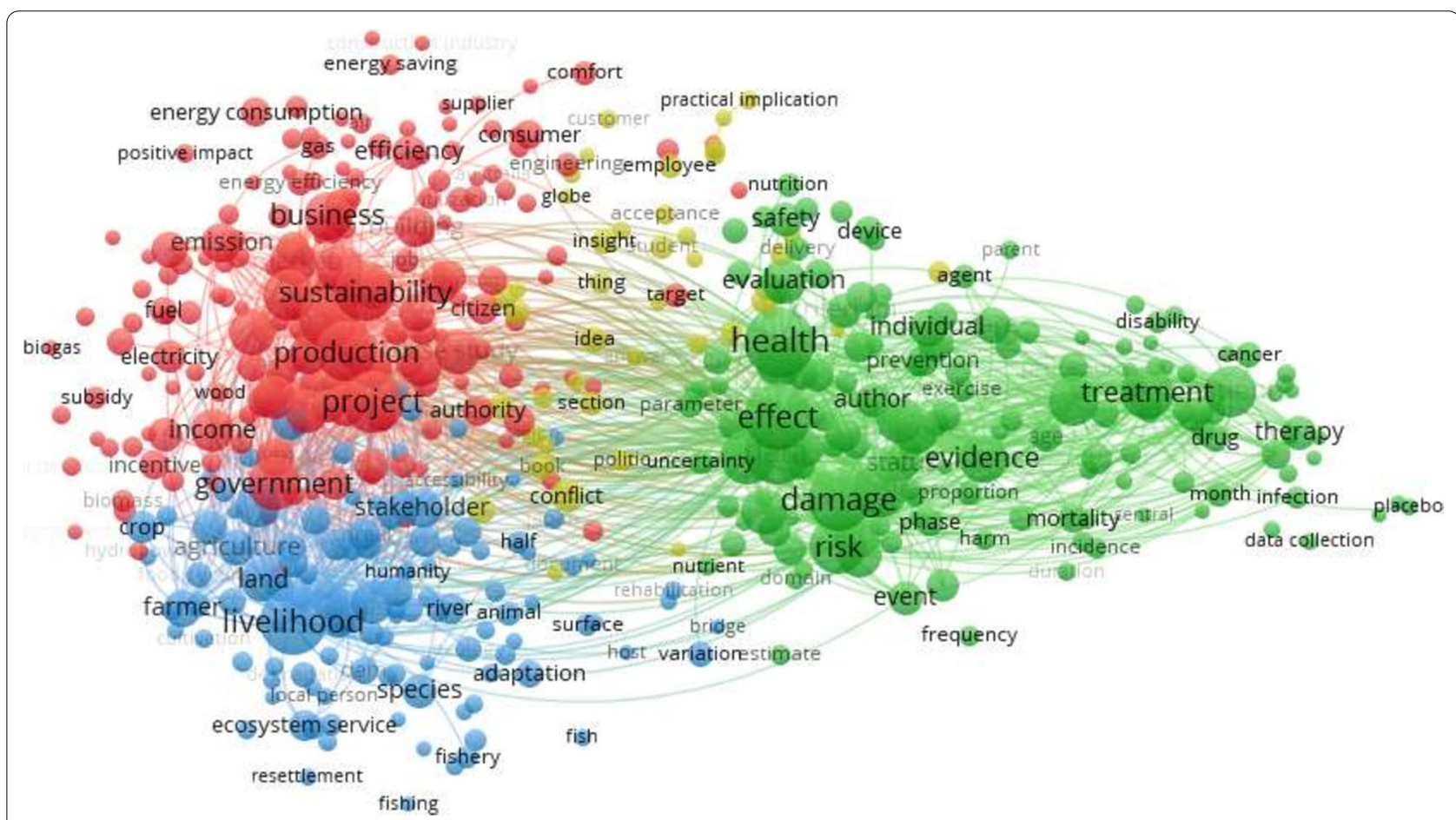

Fig. 3 Keyword co-occurrence network in the publications

Table 3 The top 10 keywords of the publications

\begin{tabular}{lllllllcc}
\hline & CLUSTER 1 & OCU & CLUSTER 2 & OCU & CLUSTER 3 & OCU & CLUSTER 4 & OCU \\
\hline 1 & Project & 167 & health & 210 & livelihood & 187 & conflict & 47 \\
2 & production & 158 & effect & 190 & climate change & 89 & sense & 35 \\
3 & sustainability & 152 & damage & 160 & land & 81 & leader & 33 \\
4 & economy & 149 & risk & 135 & conservation & 79 & actor & 32 \\
5 & government & 119 & group & 129 & ecosystem & 77 & idea & 30 \\
6 & sector & 115 & number & 127 & stakeholder & 70 & insight & 30 \\
7 & business & 97 & treatment & 123 & farmer & 63 & good & 29 \\
8 & market & 92 & patient & 110 & agriculture & 59 & wealth & 28 \\
9 & investment & 91 & disease & 104 & Natural resource & 57 & employee & 26 \\
10 & sustainable development & 91 & outcome & 99 & household & 53 & satisfaction & 24 \\
\hline
\end{tabular}

(3) the participation and relations of each component obtained through the code occurrences and co-occurrences that led to the construction of the proposed model 2.0.

\section{General results}

The 40 documents chosen under the PRISMA model showed that 2014 and 2017 were the years when most documents related to the topic were published, with seven publications each.
Furthermore, Asia was the geographical location where most studies were conducted, with $63 \%$ participation, especially with case studies in countries like Vietnam, Laos and Cambodia. It was followed by North America (17\%), Europe (12\%), Africa (5\%) and Latin America (3\%).

\section{Content analysis}

According to the literature review of 40 documents, we found, in agreement with the results shown by Model 1.0, the presence of three thematic components with 


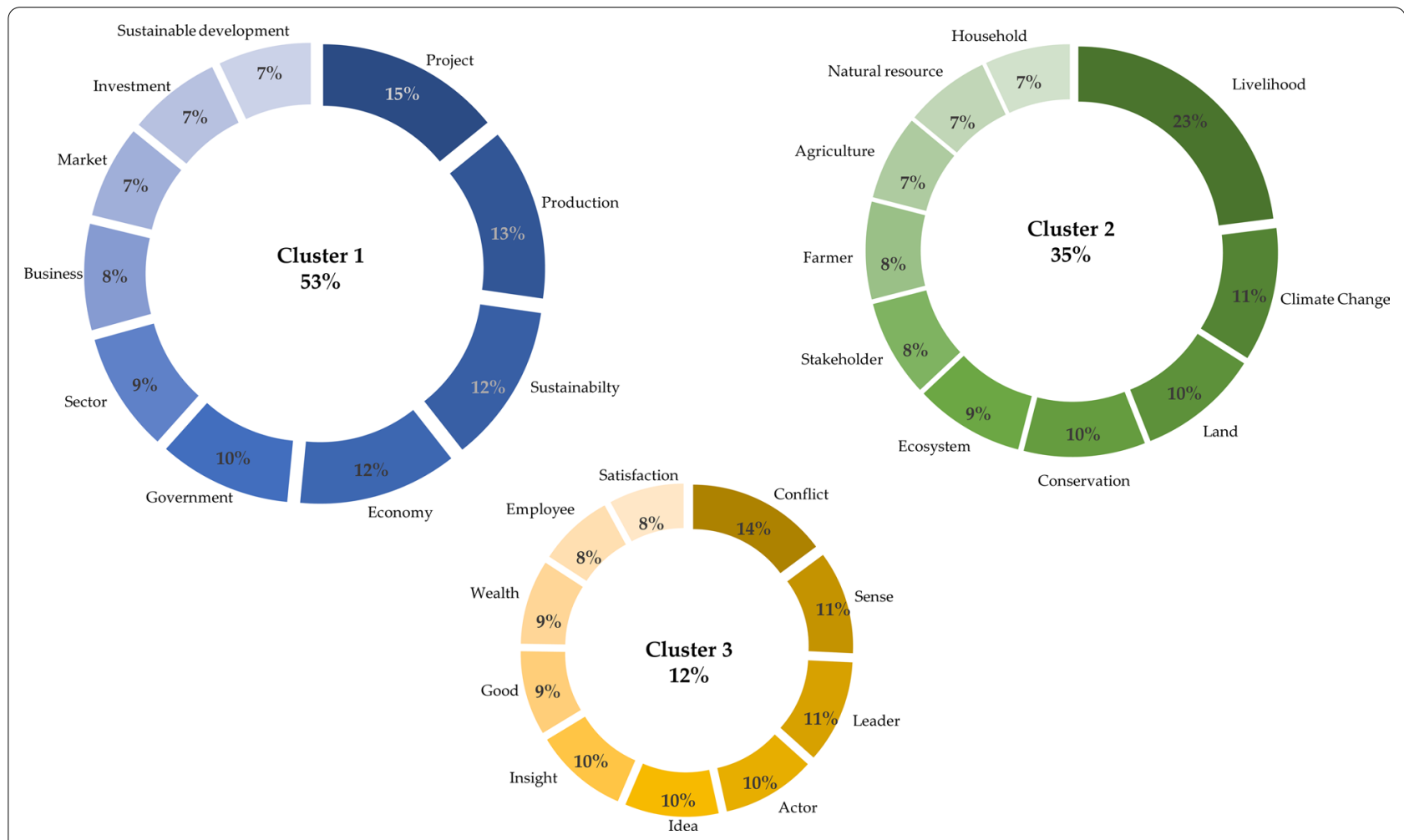

Fig. 4 Model 1.0

different theoretical scopes and degrees of participation. Specifically, the first component or group of analysis, which we called 'Corporation', showed an approach to Model 1.0 in most topics related to internal affairs that, from a corporate standpoint, frame the shared benefit scheme. However, specific topics such as market, businesses and investment, which are closely tied to business operations, did not have a major role in the documents analysed. The level of importance of this component was focused mainly on the nature of the business, sustainability and governance. This agrees with the contribution made by the authors, who highlight the need to overcome a business framework that focuses merely on economic considerations to move towards an approach that seeks to create value both for companies and the society [78, 79], i.e. to a position that moves beyond compensation, thus enabling a balance between the social, economic and environmental factors involving the installation and operation of hydropower projects [58]. Further, other authors argue that hydropower sustainability should offer a value proposal that articulates elements such as planning, construction, operation, management and governance [80]. In other words, there is a need to establish proper governance to ensure comprehensive water-use management [78].
The second component, which we called 'Society', was closely related to the topics included in Model 1.0 because elements in it were related to social and environmental impacts and effects of the execution of hydropower projects. Further, most reviewed documents are based on the predominance of issues, including the multifaceted impacts of hydropower projects in the territories where they operate that have led to countless environmental, economic and social consequences. In line with Model 1.0, some authors showed that as a result of hydropower operation, issues such as economic loss in livelihood [78], effects on ecosystem biodiversity [51] and impacts on people's relation with their territories arise [81]. These ruptures, according to Siciliano et al. [20] and Molle et al. [82], in keeping with Duarte et al. [11] and Moran et al. [9], involve not only the lack of access to water and land resources but also a dissociation from the social tissue, cultural effects and socio-environmental damage. Reviews made by authors such as Cooper [79] and Singer [81] have tackled impacts on livelihood. It was found that they are related to dropping revenues from forced resettlement because of the increase in harvesting and transportation costs as a result of reduced access to the land where raw materials are obtained, because agriculture, craftsmanship and tourism are the most frequent 
activities in these territories. Other authors such as Siciliano [20] found that impacts on people's livelihoods are related to changes in lifestyles triggered by alterations to the way they interact with their territory. Lebel et al. [21], Singer et al. [81] and Rousseau et al. [83] agree that the fear of resettlement and, mainly, the change of the dynamics in their relationship with their environment play a major role in people's livelihood and in their spirituality and beliefs. The former, according to Lebel et al. [21] and Siciliano et al. [20], would threaten people's wellbeing and affect their local culture and gender relations. Another group of authors has focused on environmental impacts that affect the ecosystem of a territory in which people are settled. This would be supported by the arguments advanced by Moran et al. [9] in line with Lebel et al. [21], Branche [78], Chauhan [84] and Siciliano et al. [20], who assert that environmental degradation, flooding, altered aquatic systems and loss of biodiversity are common consequences of the execution of hydropower projects. In agreement with Roa and Duarte [55], these environmental transformations have also had a negative impact on the livelihoods of the populations that depend on the river, jeopardising their safety and food autonomy.

Finally, although there is a strong approach between the findings of Model 1.0 and the documents chosen in relation to the third component, named 'Share Benefit', the content analysis allowed us to expand, delve into and interpret more accurately the mechanisms for enhancing shared benefit schemes. In line with Model 1.0, the studies focused mainly on the environmental, social, economic and governance-related issues caused by the disagreements between communities and officials on impact prioritisation and assessment. Authors like Rousseau et al. [83] and their research in China and Vietnam showed the prevalence of top-down governance structures, in which those benefiting are the most powerful stakeholders partaking in hydropower governance, including state-backed corporate actors in the hydropower industry.

Thus, different authors have discussed the proper governance model to allow for the concerted and comprehensive management of water resources [78] and need for greater institutional support for stakeholders to secure community rights [81]. Further, there has been considerable debate about the comprehensive guidance that should be offered at the local and national levels to ensure a broader distribution of the benefits from hydropower development, i.e. a legal support framework to manage hydropower development to ensure long-term benefits $[51,58]$. In this respect and aligned with the proposals of Model 1.0, other papers focused on the need to implement actions that call for significant participation processes that strike a balance in uneven power dynamics between stakeholders. They highlight the need for a public dialogue that enhances benefit sharing results $[79,82]$ and allows for overcoming the passive role granted so far to stakeholders as 'compensation receivers' in the benefit sharing process [54].

Further, authors like Balasubramanya et al. [85], Rousseau [83] and Suhardiman et al. [58] argue that with the exception of cases in which a community development approach is adopted, the benefits from the communities' standpoint are mostly ignored; hence, issues that are crucial in terms of livelihoods are disregarded. Furthermore, Lebel et al. [21] and Sinclair [86] agree that although all models detect common institutional challenges, engaging actors and institutions is crucial, because the most successful projects are those in which the local community is fully committed to the planning, construction and operation processes. As an extension to Model 1.0, Soliev et al. [14], in line with Lebel et al. [21], propose the need to establish a governance model for the coordinated and comprehensive management of water resources that defines parameters in terms of strategy, planning, decision-making and operation. Biedenweg et al. [87], Sparkes [80] and Soliev et al. [14] agree on the need for a comprehensive collaborative governance model that moves beyond economic compensation to offer a comprehensive overview of well-being. These facets expand Model 1.0 and support the proposed model (Version 2.0), because from a holistic view, other relations come into play that are oriented to the comprehensive sustainability of the territory from an increasingly participative standpoint $[14,88]$.

Order of importance and relation of model components

Regarding the order of importance, unlike Model 1.0, the analysed literature focused mostly on the social segment or group of analysis; that is, in relation to code occurrence, the documents examined benefit sharing models based on the social problems they addressed rather than corporate issues. This was shown (Fig. 5) by the frequency of the codes related to the category SOCIETY, which had the highest participation (42\%) with respect to total occurrences.

With regard to the category SOCIETY (Appendix, Fig. 8), livelihood and stakeholders had the biggest contribution (i.e. $35 \%$ and $34 \%$, respectively, with regard to the total occurrences in this category). In the specific case of livelihood, the impact or displacement of the lifestyles of the persons affected by the execution of hydropower projects has a significant level of occurrence [12] (50\% of total occurrences for the LIVELIHOOD code). The participation and identification of stakeholder needs played a major role in this category (76\% participation of 
the STAKEHOLDERS code). Land access, understood as the physical displacement caused by the hydropower project, in principle, [12] also reached great frequency and, according to the documents chosen, is mainly related to communities' obligation to resettle.

It is followed by the participation (38\%) of the codes related to the SHARE BENEFIT category, explained by the high contribution of codes related to CAUSES CONFLICT, understood as the factors that cause disagreements between actors involved [72] and SATISFACTION/OUTCOMES - that is, the result of the actions implemented to change an already existing condition [50]. We found (Appendix, Fig. 9) that the principal causes of conflict are those related to social and governance issues (38\% and $37 \%$, respectively).

Finally, the group of analysis related to corporate issues, unlike the results obtained in Model 1.0, had a restricted participation $(20 \%)$ in the documents analysed. With regard to the specific category CORPORATION (Appendix, Fig. 7), the issue of governance was frequently mentioned in the selected documents. This was confirmed with the high occurrence of the GOVERNMENT code, understood as the set of structures and processes that guide the activities of the project [12].

Further, in this category, sustainability had a major participation from the sustainable development perspective, because there are contributions related to the efforts needed to offer benefits other than compensation aimed at combating poverty, enhancing education and improving the economic conditions of the society [58].

With regard to relations between different segments, reflected in code co-occurrences (Table 4), the results obtained showed a higher link between BENEFIT SHARING and SOCIETY, reaching $77 \%$ of the co-occurrences, whereas the co-occurrences with the category CORPORATION stood at only $23 \%$. This is grounded on the high co-occurrence between the codes of the category BENEFIT SHARING and the LIVELIHOOD and STAKEHOLDERS codes that represent $47 \%$ of the co-occurrences between the two of them. In particular, among the most relevant results, it was found that the loss of assets, revenues or livelihood caused by the installation of hydropower companies in the territory [12] (LIVELIHOOD-ECONOMIC DISPLACEMENT) was tied to the causes of social conflict (45\% participation from total co-occurrences between CAUSES CONFLICT and LIVELIHOOD).

In addition, there was an agreement between environmental causes (CAUSES CONFLICT-ENVIRONMENTAL) of conflict and the biodiversity impacts (BIODIVERSITY ISSUES) caused by hydropower projects. These impacts were seen in the biophysical conditions of the territory, such as the fragmented fluvial systems, vegetation, effects on soil and water quality and species composition [20]. Because of these effects on the communities' livelihoods, lifestyle and, hence, well-being, hydropower watersheds have become places of social conflict [21]. Moreover, the monetary and non-monetary activities (MONET-ACT AND NON-MONET-ACT) that are usually offered as compensation and resettlement mechanisms are closely related to the displacement of and opportunities granted to communities. Some opportunities, for example, are capacity development [51] and improvements in infrastructure, health services

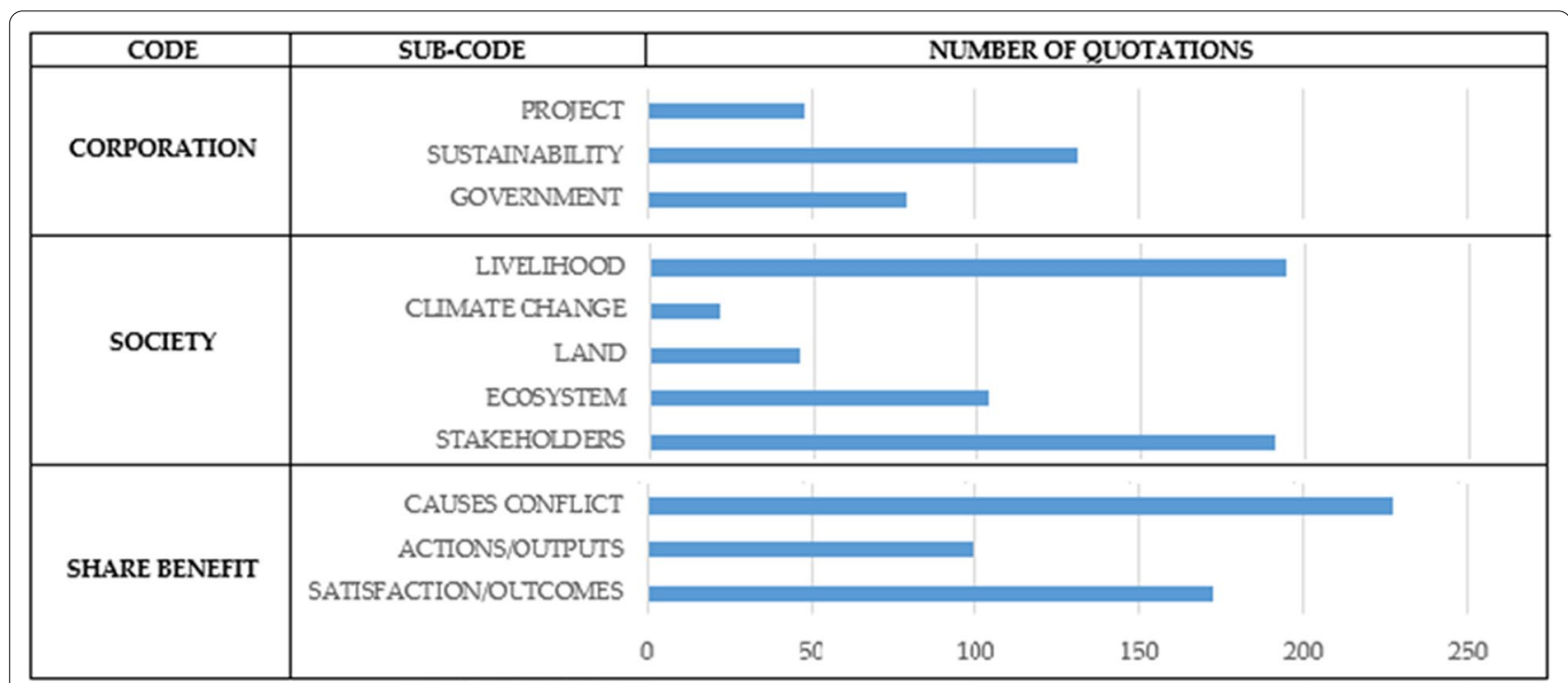

Fig. 5 Number of codes' quotations 


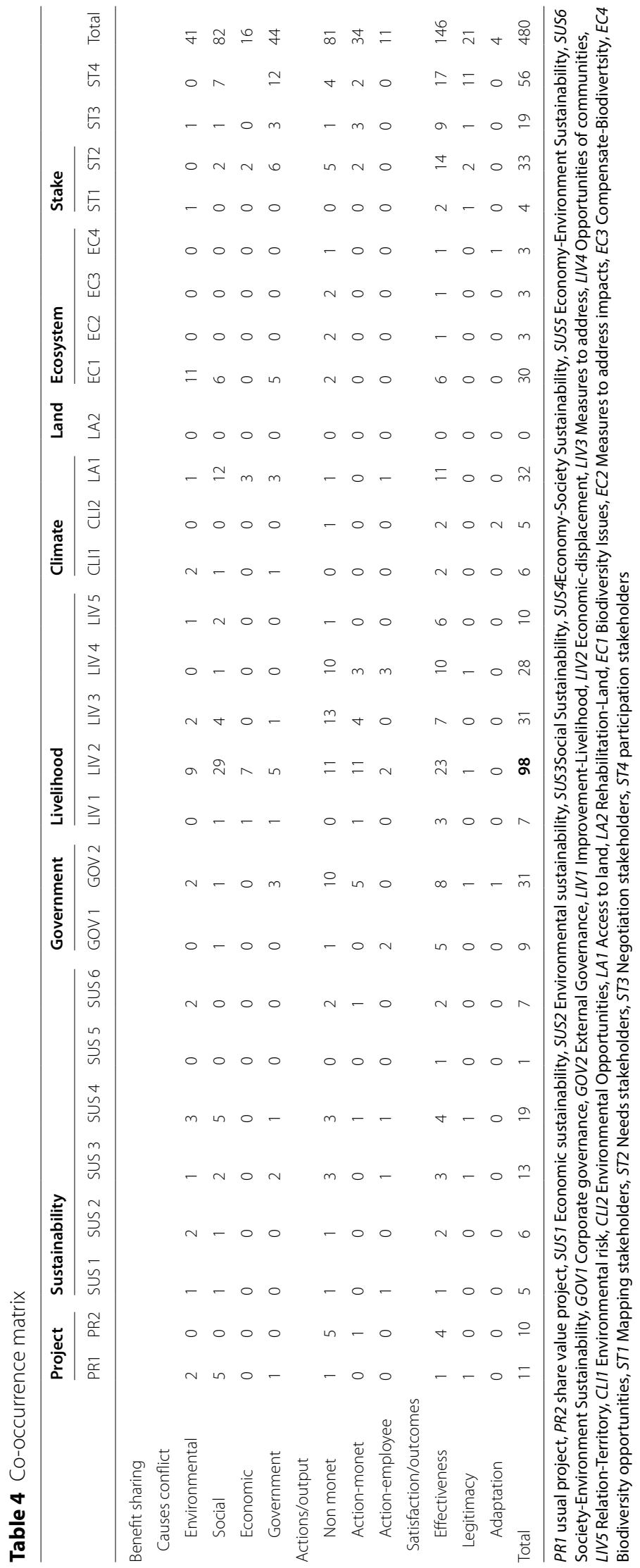


and education [81]. In light of the significant associations between the subcodes LIVELIHOOD-ECONOMIC DISPLACEMENT and LIVELIHOOD-OPPORTUNITIES with OUTCOMES-EFFECTIVENESS (45\% and 20\% with respect to total co-occurrences between LIVELIHOOD and OUTCOMES), the relation between loss and new livelihoods for the communities affected by hydropower projects and the efficiency of the benefit sharing initiatives makes sense.

Based on the results that were obtained previously from reviewing the literature on benefit sharing, we built Version 2.0 of the model (Fig. 6). This model shows the findings obtained with respect to the weights of the occurrences, co-occurrences and content of the 40 documents that were analysed.

This conceptual model helped us offer a closer approach to the nature and sense of the actions of companies and social actors to ensure shared benefits with respect to the initial model 1.0.

\section{Discussion}

Model 2.0 proved the need for a holistic and participative approach to benefit sharing in the hydropower sector that broadens the initial proposals made by authors like Dombrowsky et al. [22], who focused on examining whether revenue-based distribution ensures long-term benefits for the population, as well as authors like Moran et al. [9], who addressed the unsustainability of current benefit sharing practices.

Model 2.0 is consistent with the prior proposals of Jorda and Rodríguez [59], who insist that the institutional mechanisms of local representation yield better results, because local communities are empowered and assume ownership of projects. It is also aligned with Pulice et al. [23], who emphasise the importance of basing the quality of these systems on the establishment of formal rules and stakeholder engagement in the distribution of financial resources and adaptation management. Furthermore, the relation between sustainability and governance and efficient benefit sharing models is consistent with the statements made by Sadoff and Grey [57], because the model suggests that corporate sustainability and governance methods may encourage the integration of the community into these processes as well as fair and efficient access to benefits, contributing to well-being and quality of life.

Thus, Model 2.0 demonstrated the importance of Wang's approaches [13]. Wang asserted the urgency of

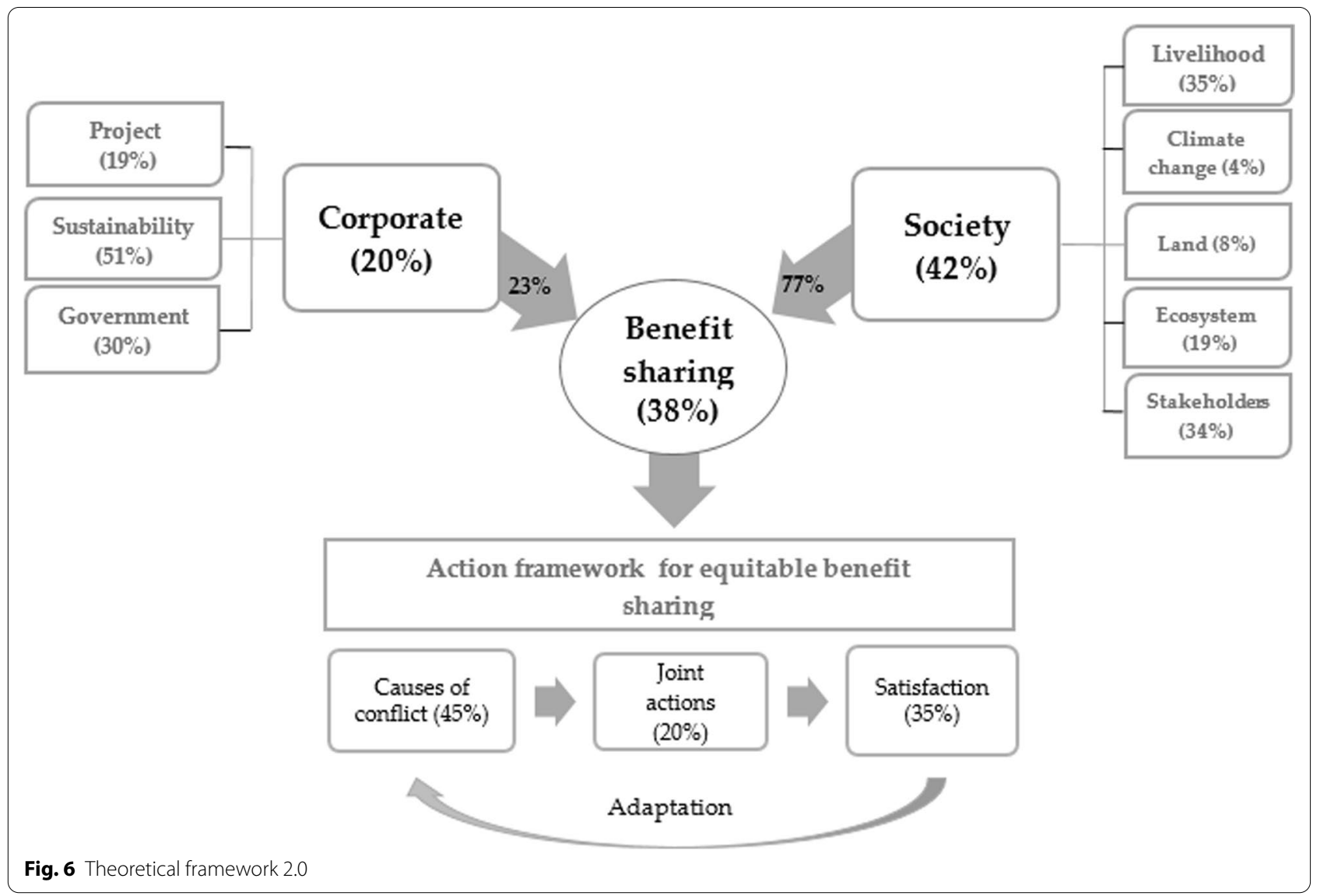


moving beyond compensation-based benefit sharing models. Model 2.0 also showed a strong relation between stakeholder engagement and the identification of their needs with the efficiency of benefit sharing mechanisms, as stated by Jorda and Rodríguez [59] and Pulice et al. [23]. Moreover, with regard to the degree of importance of topics, such as access to and relation with the territory, the model was consistent with the position of authors like Melamed et al.[88], who espouse an increasingly participative and holistic perspective on the relation with territory. The results also ratify the position of Roa and Avendaño [55] and Rousseau et al. [83], who propose moving beyond the economic assessment of wellbeing, attaching value to the interaction with nature and social and cultural and spiritual relations. In this sense, the model proposed herein upholds the statements made by Duarte et al. [11], because water governance seeks to promote stakeholder engagement based on local appraisals as well as the cultural understanding and local significance of nature and livelihood [11].

The model of action proposed in this study is the result of the identification, analysis and reflections of governance models for the distribution of benefits in different experiences worldwide in the energy sector. Its results are validated by finding a strong approach to the contributions that form different case studies of the energy sector towards the consolidation of an optimal distribution policy model of the shared benefit. One case that we can highlight is that of the energy companies of Northern Russia and Northern Alaska. Tysiachniouka \& Petrovc [19] argue that the differences in the shared benefit agreements are related to the company's own issues from the expectations imposed by investors, the existing legislation and the level of empowerment of the local communities. Likewise, this study reaffirms the importance of the policy of distribution of benefits in the livelihoods of the residents of these territories. In this sense, as evidenced in Model 2.0, this case study proposes that, ideally, the concept of benefit sharing will be combined with actions oriented from principles based on equity, distributive justice and transparency, i.e. from the ability to participate in decision-making related to benefits as well as the ability to receive benefits that go beyond compensation and therefore lead to the improvement of the wellbeing of local communities.

Another case where an approximation to our model can be evidenced from its findings and reflections regarding its policy of distribution of the shared benefit is that of the Kamchay hydroelectric plant in Cambodia. Sicialiano [20] starts by raising the need to harmonise corporate priorities and local communities in all phases of the construction of the hydroelectric plant. Likewise, based on the impacts achieved in different economic, social and environmental dimensions, that deeply affects the livelihoods of local communities. Impacts on flora and fauna and changes in the ecosystem, as well as negative economic impacts, especially for the most impoverished populations. The great divergence that continues to exist between the prioritisation and evaluation of the impacts between local residents and government officials is evident as the origin of the causes of the conflict. In this sense and in coherence with the proposed model, the need for a balance between national and local interests is validated as the main cause of conflict, in addition to the lack of effectiveness of mitigation and compensation strategies. This case study reaffirms the need for joint actions that, from a political commitment, encourage participatory strategies of interest groups, taking into account the specificities of the affected communities.

Finally, in the Latin American context, the model proposed here supports the quantitative results that have been achieved in the evaluation of the distribution of benefits in the case of hydroelectric plants in Brazil [23]. In this sense, their findings show that, in a manner consistent with Model 2.0, the need to consider management frameworks that include legal and formal parameters, stakeholder participation and adaptation management prevails, key factors for a broader vision of the affected areas and people. All of the above, complemented by optimal planning and management of resources for financial compensation, may lead to the improvement of local development.

The operational model confirms the need for governance systems that are more flexible and adaptable to the way water and its benefits are distributed, considering the changes in social and environmental requirements and values. As stated by Roa and Avendaño [55], this would help overcome conflicts arising from the asymmetric negotiation that favours companies and disrupts community processes. In other words, as proposed by Sadoff and Grey [57] and Soliev et al.[14], the operational model proposed adopts an adaptation approach that includes stakeholder engagement, negotiation, gains and an understanding of the communities' abilities and capabilities.

\section{Conclusions}

We designed a theoretical operational framework for benefit sharing between hydropower companies and local communities. Under the operational framework proposed, benefit sharing showed different specific weights for hydropower companies and society-specifically, local communities-defining collaborative governance as the method of organisation. The contributions to benefit sharing from the standpoint of the society are more frequent, indicating the importance of stakeholders and 
their livelihoods. Corporate contributions are important in terms of sustainability and corporate governance. The problem of the even distribution of shared benefits was addressed, in most cases, with a focus on collaboration. This type of company-society relation greatly focused on conflicts and their causes rather than on joint actions and their results.

The proposal for benefit sharing between hydropower companies and local communities was developed after applying a sequential mixed method that consisted, first, of a bibliometric analysis and, then, of a content analysis, which led to the construction of a shared benefit theoretical operational framework. This methodological sequence allowed us to examine the recent status of the debate from an intermediate perspective, which combines the inherent positivism in bibliometric methods and their objectivity with the subjectivity of the intersubjective interpretations of content analysis.

Despite the preponderance of the social component in the operational framework, the notion of well-being prevailed over the notion of good living. The analysed literature generally addressed the material assets related to livelihood rather than non-material assets such as culture and religion. By contrast, the notion of corporate sustainability was tackled by the model from a business performance standpoint because business impacts and corporate governance are important. The relation between good living and corporate sustainability was possible because of the notion of shared value, evidencing the importance of satisfaction with the results. The results of the joint actions between companies and society such as compensation were not as important as their efficiency and legitimacy. Therefore, the theoretical operational framework showed that the equal distribution of shared benefits would be the result of an adaptive stateled organisational process to reduce power asymmetries between companies and society.

In the hydropower sector, the products and results of the joint action between companies and society showed the need to solve the social conflicts caused by the loss of the local communities' income and livelihoods. Communities are usually affected by population displacement, fragmented fluvial systems, deforestation, soil erosion and water contamination. However, compensation and resettlements were a result of a joint action that failed to ensure an equal distribution of benefits because of the lack of efficiency and legitimacy. In most cases, they were products defined by the company without the communities' involvement from the early stages of the project and disregarding the intangible values of the territory. Although the examined literature focused on social considerations instead of corporate factors, corporate interests prevailed in the cases studied as a consequence of power asymmetries. The operational framework establishes that equity would be the result of joint actions aimed at addressing the causes of social, environmental and economic impacts, moving beyond compensation to contribute to communities' good living. These actors' satisfaction with the results of the initiatives launched would determine the efficiency and legitimacy of the results of collaborative governance in relation to the hydropower plant. However, this is an adaptive process because it depends on companies' performance, communities' level of empowerment and the state's capacity to intervene in setting rules of engagement to help reduce power asymmetries between companies and society.

Our theoretical proposal, with its analytical scope, acts like a framework that can be applied in future studies. In this sense, we believe that future research should include empirical data on the social, environmental and economic impacts of active hydropower plants and compare them with the information on management strategies and the relations between power companies, state-run entities and local communities. The relation between equal benefit sharing and collaborative governance under the proposed operational framework could thus be assessed. This means that in future studies, academics and practitioners may apply our theoretical proposal to discover territorial particularities and effectively assign resources accordingly to the stakeholders' needs, specifically for the community and environment.

\section{Appendix}

See Figs. 7, 8 and 9. 


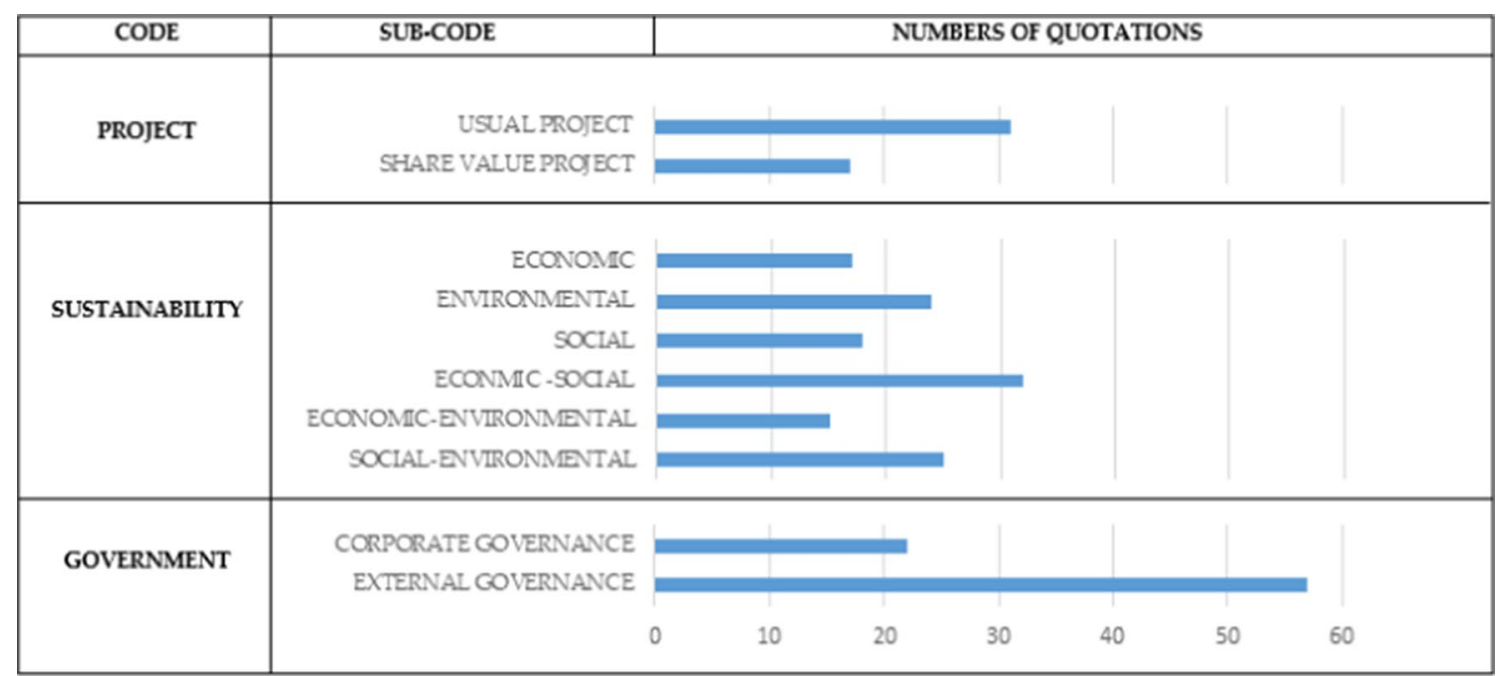

Fig. 7 Corporate category. Numbers of code's quotations

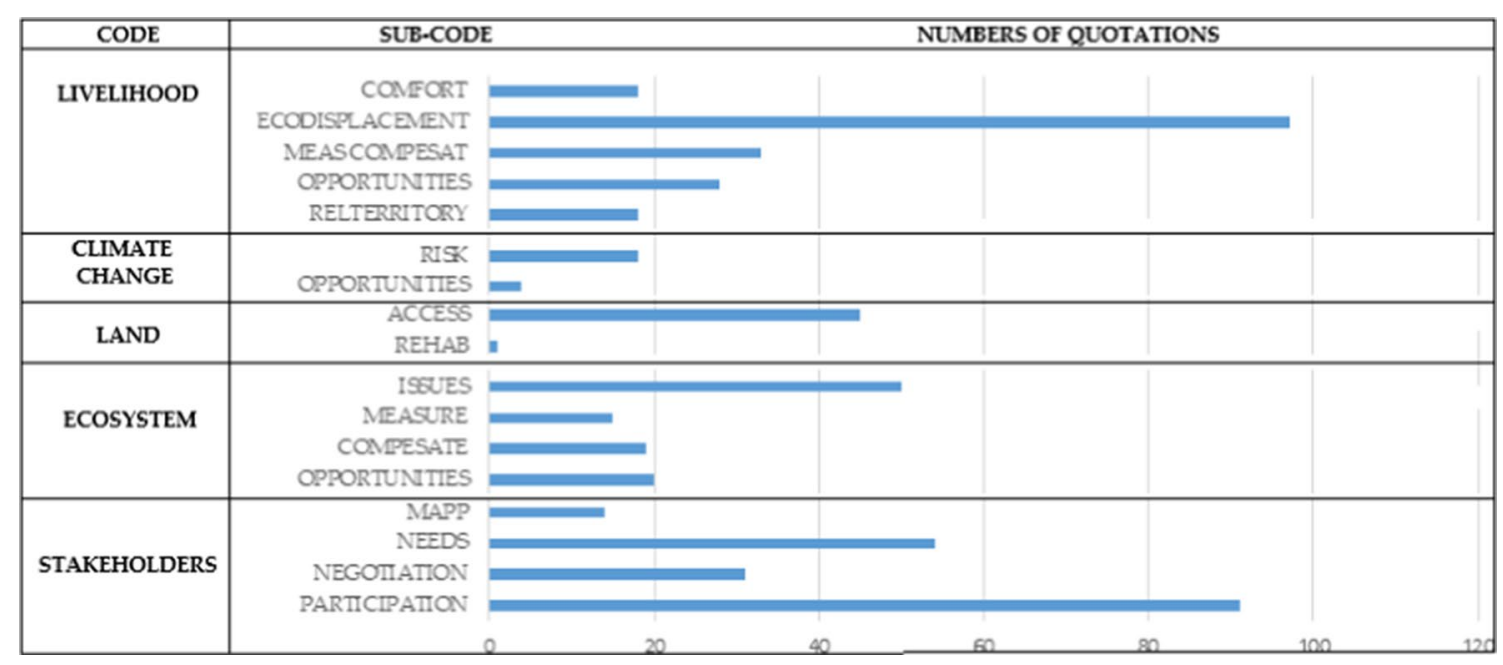

Fig. 8 Society category. Numbers of code's quotations

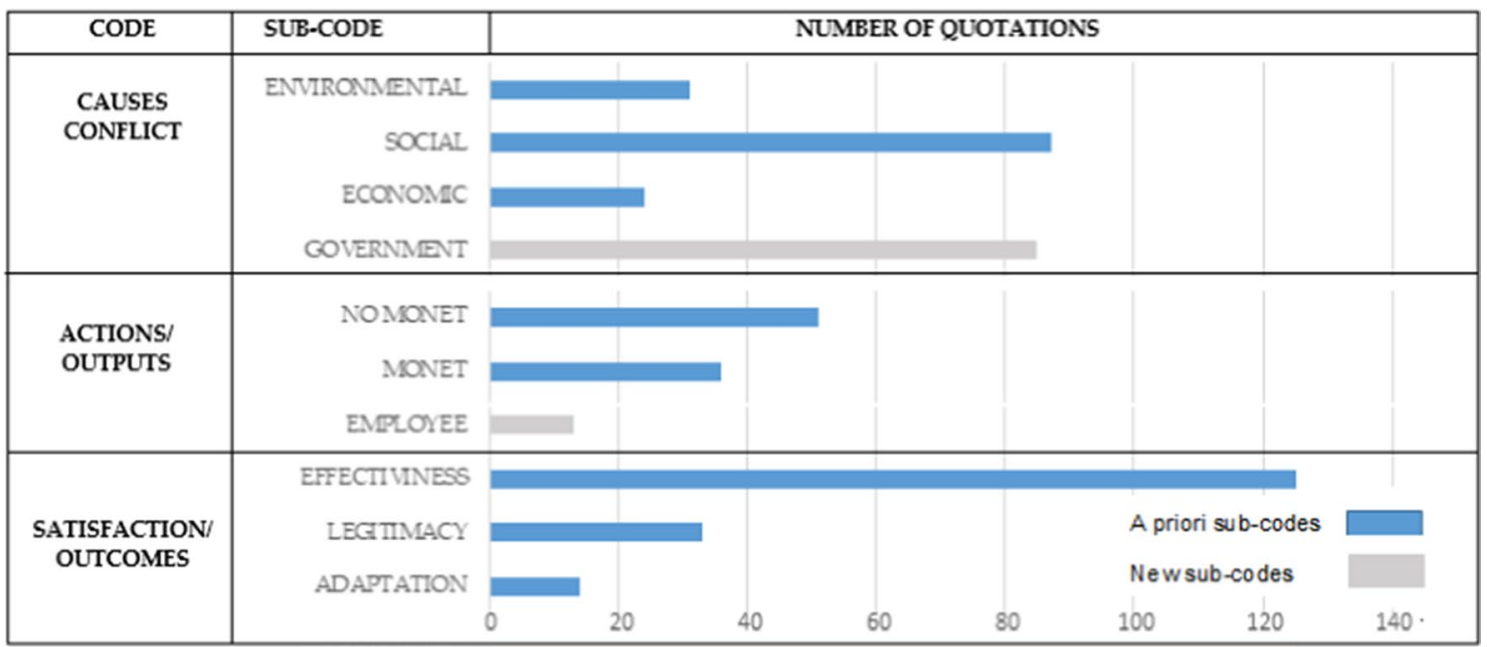

Fig. 9 Benefit sharing category. Numbers of code's quotations 


\section{Acknowledgements}

The authors thank Crimson Interactive Pvt. Ltd. (Enago)—https://www.enago. $\mathrm{com} / \mathrm{es} /$ for their assistance in manuscript translation and editing.

\section{Authors' contributions}

Gathered and organised the information included in this review IJI; conceptualisation, and writing - IJ-I, J-AP and ME-S; methodological supervision, MES; general supervision J-AP. All authors have read and agreed to the published version of the manuscript. All authors read and approved the final manuscript.

\section{Funding}

Ministry of Science, Technology and Innovation (MinCiencias) through the contract 80740-453-2019 (Convocatoria 811-2019 Postdoctoral Fellowship) and University of Medellín 2019-2020, Colombia, supported this research.

\section{Availability of data and materials}

Not applicable.

\section{Declarations}

Ethics approval and consent to participate

Not applicable.

\section{Consent for publication}

Not applicable.

\section{Competing interests}

The authors declare no conflict of interest.

Received: 26 June 2020 Accepted: 11 March 2021

Published online: 25 March 2021

\section{References}

1. Samaniego JL (2014) La economía del cambio climático. In América Latina y el Caribe: paradojas y desafíos del desarrollo sostenible. Santiago de Chile. https://repositorio.cepal.org/bitstream/handle/11362/37791/ LCM23_es.pdf. Accessed 18 Jan 2020

2. Polanco J, Ramírez F (2017) Evaluación de la sostenibilidad en empresas energéticas. Una investigación aplicada a centrales de generación hidroeléctrica. Universidad de Medellín \& Isagen, Medellín

3. Marañón B (2014) Buen vivir y descolonialidad. Crítica al desarrollo y la racionalidad instrumentales. https://doi.org/10.1016/j.rpd.2015.03.010

4. Acosta A (2013) Buen vivir. Sumak Kawsay, una oportunidad para imaginar nuevos mundos. Ediciones Abya Yala, editor. Quito

5. Vanhulst J (2013) El Buen vivir : una utopía latinoamericana en el campo discursivo global de la sustentabilidad. P Rev Latinoam 12(36):497-522

6. Gudynas E (2011) Buen Vivir: Germinando alternativas al desarrollo. América Lat en Mov. 462)

7. Porter M, Kramer M (2011) Creating shared value. Harvard Bus Rev América Lat. 56(1):3-18. http://www.filantropia.org.co/archivo/attachments/ article/198/SharedValueinSpanish.pdf. Accessed 14 sept 2019

8. Naciones Unidas (2005) Declaración de Brisbane sobre Participación de la Comunidad Brisbane. Available via: https://www.lcsansw.org.au/docum ents/item/330. Accessed 17 oct 2019

9. Moran E, López MC, Moore N, Müller N, Hyndman D (2018) Sustainable hydropower in the 21st century. Proc Natl Acad Sci USA 115(47):1189111898. https://doi.org/10.1073/pnas.1809426115

10. Zarfl C, Lumsdon AE, Berlekamp J, Tydecks L, Tockner K (2014) A global boom in hydropower dam construction. Aquatic Sci 77(1):161-70. https://doi.org/10.1007/s00027-014-0377-0

11. Duarte-Abadia B, Rutger B, Roa-Avendaño T (2015) Hydropower, encroachment and the re-patterning of hydrosocial territory: the case of hidrosogamoso in Colombia. Human Org 74(3):243-54.

12. iha Hydropower Sustainability Assessment Protocol (2018) London, UK. 1-221.doi:https://doi.org/10.1111/fcre.12351

13. Wang C. A (2012) Guide for Local Benefit Sharing in Hydropower Projects. Social development papers. Washington. www.worldbank.org/socialdeve lopment\%0AThis. Accessed Mar 2020
14. Soliev I, Wegerich K, Kazbekov J (2015) The costs of benefit sharing: Historical and institutional analysis of shared water development in the Ferghana Valley, the Syr Darya Basin. Water (Switzerland) 7(6):27282752. https://doi.org/10.3390/w7062728

15. UNEP (2007) Dams and Development. Relevant practices for improved decision-making, Nairobi

16. Choudhury NB, Dey Choudhury SR (2020) Implications for planning of hydroelectric projects in Northeast India: an analysis of the impacts of the Tipaimukh project. GeoJournal. p. 1-21. doi:https://doi.org/10. 1007/s10708-020-10158-8

17. Huđek H, Žganec K, Pusch MT (2020) A review of hydropower dams in Southeast Europe - distribution, trends and availability of monitoring data using the example of a multinational Danube catchment subarea. Renew Sustain Energy Rev 117:109434. https://doi.org/10.1016/j.rser. 2019.109434

18. Nautiyal H, Goel V (2020) Sustainability assessment of hydropower projects. J Clean Prod 265:1-14. https://doi.org/10.1016/j.jclepro.2020. 121661

19. Tysiachniouk MS (2017) Benefit sharing in the Arctic energy sector: perspectives on corporate policies and practices in Northern Russia and Alaska. Energy Res Soc Sci 39:29-34. https://doi.org/10.1016/j.erss. 2017.10.014

20. Siciliano G, Urban F, Kim S, Lonn P (2015) Hydropower, social priorities and the rural-urban development divide: the case of large dams in Cambodia. Energy Policy 86:273-285. https://doi.org/10.1016/j.enpol. 2015.07.009

21. Lebel L, Lebel P, Chitmanat C, Sriyasak P (2014) Benefit sharing from hydropower watersheds: Rationales, practices, and potential. Water Resour Rural Dev 4(C):12-28. doi:https://doi.org/10.1016/j.wrr.2014.10. 006

22. Dombrowsky I, Bastian J, Däschle D, Heisig S, Peters J, Vosseler C (2014) International and local benefit sharing in hydropower projects on shared rivers: The Ruzizi III and Rusumo Falls cases. Water Policy 16(6):1087-1103. https://doi.org/10.2166/wp.2014.104

23. Pulice SMP, Branco EA, Gallardo ALCF, Roquetti DR, Moretto EM (2019) Evaluating monetary-based benefit-sharing as a mechanism to improve local human development and its importance for impact assessment of hydropower plants in Brazil. J Environ Assess Policy Manag 21:1. https://doi.org/10.1142/S1464333219500030

24. Li D, Zhao J, Govindaraju RS (2019) Water benefits sharing under transboundary cooperation in the Lancang-Mekong River Basin. J Hydrol 577:123989. https://doi.org/10.1016/j.jhydrol.2019.123989

25. Prebish R (1991) El desarrollo económico de la América Latina y algunos de sus principales problemas. Santiago de Chile. https://repos itorio.cepal.org/bitstream/handle/11362/40010/prebisch_desarrollo_ problemas.pdf. Accessed 15 Mar 2020

26. Keeble BR (1988) The Brundtland report:'Our common future.' Med War. $4(1): 17-25$

27. Pacheco DF, Dean TJ, Payne DS (2010) Escaping the green prison: Entrepreneurship and the creation of opportunities for sustainable development. J Bus Ventur 25(5):464-480. https://doi.org/10.1016/j. jbusvent.2009.07.006

28. Matten D, Moon J (2008) "Implicit" and "explicit" CSR: A conceptual framework for a comparative understanding of corporate social responsibility. Acad Manag Rev 33(2):404-24. https://doi.org/10.5465/ AMR.2008.31193458

29. Powell W, DiMagio P (1991) The new institutionalism in organizational analysis. Chicago University Press, Chicago

30. Conner K, Prahalad C (1996) A resource-based theory of tyhe firm: konowledge versus opportunism. Organ Sci 7(5):477-501. https://doi. org/10.1287/orsc.7.5.477

31. Wernerfelt B (1984) A resource-based view of the firm. Strateg Manag 5(2):171-80. http://web.mit.edu/bwerner/www/papers/AResourceBasedViewoftheFirm.pdf. Accessed 23 Feb 2020

32. Freeman RE, Wicks AC, Parmar B (2004) Stakeholder theory and "The Corporate Objective Revisited." Organ Sci 15(3):364-369. https://doi. org/10.1287/orsc. 1040.0066

33. Meyer J, Rowan B (1997) Institutionalized Organizations: Formal Structure as Myth and Ceremony. Am J Sociol 83:340-363. https://doi.org/ $10.1086 / 226550$ 
34. DiMaggio P, Powell W (1983) The iron cage revisited: Institutional isomorphism and collective rationality in organizational fields. Am Sociol Rev 48(2):147-160. https://doi.org/10.2307/2095101

35. Prahalad C, Hamel G (1990) The core competence of the corporation. Harv Bus Rev 68:79-91. https://doi.org/10.1007/3-540-30763-X_14

36. Freeman RE (1984) Strategic Management: A Stakeholder Approach. Pitman/Bal, Boston

37. Freeman RE, Harrison J, Wicks AC, Parmar B, De Colle S, Purnell L (2010). Stakeholder theory: The state of the art. https://doi.org/10.1080/19416 520.2010 .495581

38. Montiel I, Delgado-Ceballos J (2014) Defining and measuring corporate sustainability: are we there yet? Organ y Environ 27(2):113-139. https://doi.org/10.1177/1086026614526413.

39. Paternoster A (2011) Herramientas para medir la sostenibilidad corporativa: un análisis comparativo de las memorias de sostenibilidad. Universitat Politècnica de Catalunya, España

40. Aguado M, Calvo D, Dessal C, Riechmann J, González J a, Montes C (2012) La necesidad de repensar el bienestar humano en un mundo cambiante. Papeles Relac ecosociales y cambio Glob 119(2):49-76. https://www.fuhem.es/papeles_articulo/la-necesidad-de-repensar-elbienestar-humano-en-un-mundo-cambiante. Accessed 3 Feb 2020

41. Viola A (2014) Discursos "pachamamistas" versus políticas desarrollistas: el debate sobre el Sumak Kawsay en los Andes. Íconos 48:55-72. https://doi.org/10.17141/iconos.48.2014.1209

42. Max-Neef M (1993) Desarrollo a escala humana: conceptos, aplicaciones y algunas reflexiones. Icaria, Barcelona

43. Alguacil Gómez J (2004) La calidad de vida y el tercer sector: nuevas dimensiones de la complejidad. Cuad Investig urbanística (42):35-48. http://polired.upm.es/index.php/boletincfs/article/viewFile/2736/ 2800. Accessed 15 Feb 2020.

44. Santana M (2015) El buen vivir, miradas desde adentro. Rev Pueblos y Front 10:171-198. https://doi.org/10.22201/cimsur.18704115e.2015.19. 50

45. Acosta A (2015) El Buen Vivir como alternativa al desarrollo. Algunas reflexiones económicas y no tan económicas [Internet]. Vol. 52, Politica y Sociedad p. 299-330. doi:https://doi.org/10.5209/rev_POSO.2015. v52.n2.45203

46. PNUMA - UNEP (2012). Informe Final de la XVIII Reunión del Foro de Ministros de Medio Ambiente de América Latina y el Caribe. Quito. https://www.yumpu.com/es/document/read/5568092/informe-finalde-la-xviii-reunion-del-foro-de-ministros-de-medio. Accessed 4 Feb 2020

47. Gudynas E, Acosta A (2011) El buen vivir o la disolución de la idea del progreso. La medición del progreso y del bienestar. Propuestas desde América Latina 03-10. Available via: http://www.gudynas.com/publicacio nes/capitulos/GudynasAcostaDisolucionProgresoMx11r.pdf. Accessed 3 Feb 2020

48. Pfitzer M, Bockstette V, Stamp M (2013) Innovating for shared value. Harv Bus Rev 91(9). Available from: https://hbr.org/2013/09/innovating-forshared-value. Accessed 3 Feb 2020

49. Ansell C, Gash A (2008) Collaborative Governance in the Theory and Practice. J Public Adm Res Theory 18(4):543-571. https://doi.org/10.1093/ jopart/mum032

50. Emerson K, Nabatchi T, Balogh S (2012) An integrative framework for collaborative governance. J Public Adm Res Theory 22(1):1-29. https://doi. org/10.1093/jopart/mur011

51. Men P, Thun V, Yin S, Lebel L (2014) Benefit sharing from Kamchay and Lower Sesan 2 hydropower watersheds in Cambodia. Water Resour Rural Dev 4:40-53. https://doi.org/10.1016/j.wrr.2014.10.004

52. Shi G, Shang K (2020) Land asset securitization: an innovative approach to distinguish between benefit sharing and compensation in hydropower development. Impact Assess Proj Apprais 1-12

53. Domingues GF, Simões Alves LG, Ferraz Rosa LM, Aquino de Souza GS, Barbosa RA, Lorenzon AS (2019) Financial compensation in hydropower generation: A tool for social and environmental development. Water Policy 21(6):1239-1250. https://doi.org/10.2166/wp.2019.007

54. Xia B, Qiang M, Chen W, Fan Q, Jiang H, An N (2018) A benefit sharing model for hydropower projects based on stakeholder input-output analysis : A case study of the Xiluodu Project in China. Land use policy 73:341-352. https://doi.org/10.1016/.landusepol.2018.02.002
55. Roa Avendaño T, Duarte B (2013) Desarrollo hidroeléctrico, despojo y transformación territorial: El caso de Hidrosogamoso, Santander, Colombia. In: Aguas Robadas Despojo Hídrico y Movilización Social. Available via: https://totumasymaracas.files.wordpress.com/2013/10/doc_tati-bibi_ art-hidrosogamoso_aguas-robadas_2013_rfinal.pdf. Accessed 13 Jan 2020

56. Cáceres ND (2015) La Creación De Valor Compartido: Estrategia De Sostenibilidad Y Desarrollo Empresarial. Cult Latinoam 22(2):207-30. https:// editorial.ucatolica.edu.co/index.php/RevClat/article/view/1629. Accessed 13 Jan 2020

57. Sadoff CW, Grey D (2002) Beyond the river: The benefits of cooperation on international rivers. Water Policy 4(5):389-403. https://doi.org/10. 1016/S1366-7017(02)00035-1

58. Suhardiman D, Wichelns D, Lebel L, Sellamuttu SS (2014) Benefit sharing in Mekong Region hydropower: Whose benefits count? Water Resour Rural Dev 4:3-11. https://doi.org/10.1016/j.wrr.2014.10.008

59. Jorda-Capdevila D, Rodriguez-Labajos B (2017) Socioeconomic value(s) of restoring environmental flows: systematic review and guidance for assessment 320:305-20. doi:https://doi.org/10.1002/rra.3074

60. Green BN, Johnson CD, Adams A (2006) Writing narrative literature reviews for peer-reviewed journals: secrets of the trade. J Chiropr Med 5(3):101-117

61. Mikalef P, Pappas IO, Krogstie J, Giannakos M (2018) Big data analytics capabilities: a systematic literature review and research agenda. Inf Syst E-bus Manag 16(3):547-578

62. Kastner M, Tricco AC, Soobiah C, Lillie E, Perrier L, Horsley T (2012) What is the most appropriate knowledge synthesis method to conduct a review? Protocol for a scoping review. BMC Med Res Methodol 12(1):1-7

63. Flick U (1992) Triangulation revisited: strategy of validation or alternative? J Theory Soc Behav 22(2):175-197

64. Cortés-Pérez HD, Escobar-Sierra M, Galindo-Monsalve R (2020) Influence of lifestyle and cultural traits on the willingness to telework: a case study in the Aburrá Valley Medellín Colombia. Glob Bus Rev. https://doi.org/10. 1177/09721509209160726072

65. Stemler S (2000) An overview of content analysis. An overview of content analysis. Pract Assessment, Res Eval 7:1-7. https://doi.org/10.7275/ z6fm-2e34

66. Moher D, Liberati A, Tetzlaff J, Altman DG (2009) Preferred reporting items for systematic reviews and meta-analyses: the PRISMA statement. BMJ 339:332-336. https://doi.org/10.1136/bmj.b2535

67. Corbin J, Strauss A (1990) Grounded theory research: procedures, canons, and evaluative criteria. Qual Sociol 13(1):3-21

68. Schlosser R, Wendt O, Bhavnani S, Nail-Chiwetalu B (2006) Use of information-seeking strategies for developing systematic reviews and engaging in evidence-base practice: the application of tradictional and comprehensive pearl growing-a review. Int J Lang Commun Disord 41:5. https://doi.org/10.1080/13682820600742190

69. Van Eck NJ, Waltman L (2015) Accuracy of citation data in Web of Science and Scopus. J Organomet Chem 798:229-233

70. Van Eck NJ, Waltman L (2014) Visualizing Bibliometric Networks. Measuring Scholarly Impact 285-320 p. doi:https://doi.org/10.1007/978-3-31910377-8_13

71. Flick U (2004) Investigación cualitativa: relevancia, historia y rasgos. In: Introducción a la investigación cualitativa. Ediciones. Madrid p. 16-51.

72. Lozano R (2015) A holistic perspective on corporate sustainability drivers. Corp Soc Responsib Environ Manag 22(1):32-44. https://doi.org/10.1002/ csr.1325

73. Emerson K, Nabatchi T (2015) Evaluating the productivity of collaborative governance regimes: a performance matrix. Public Perform Manag Rev 38(4):717-747. https://doi.org/10.1080/15309576.2015.1031016

74. Muise S (2020) Hydro Power. Student energy. https://www.studentene rgy.org/topics/hydro-power\#reference-1. Accessed 13 Jan 2020

75. Denzin NK (1970) Sociological Methods A Sourcebook. Aldine Pub, Chicago

76. Olsen W (2004). Triangulation in Social Research: Qualitative and Quantitative Methods Can Really Be Mixed. In: Developments in Sociology Ormskirk: Causeway Press. Pp 1-12. doi:https://doi.org/10.1023/A:10247 56526171

77. Polanco J (2018) Exploring governance for sustainability in contexts of violence: The case of the hydropower industry in Colombia. Energy Sustain Soc 8:1. https://doi.org/10.1186/s13705-018-0181-0 
78. Branche E (2017) The multipurpose water uses of hydropower reservoir the SHARE concept. Comptes Rendus Phys 18:469-478. https://doi.org/ 10.1016/j.crhy.2017.06.001

79. Cooper R (2012) The Potential of MRC to Pursue IWRM in the Mekong: Trade-offs and Public Participation. In: Öjendal J, Hellberg S, Stina Hansson (eds) Politics and Development in a Transboundary Watershed $p$. 61-82. doi: https://doi.org/10.1007/978-94-007-0476-3

80. Sparkes S (2014) Sustainable hydropower development: Theun-Hinboun expansion project case study, Laos. Water Resour Rural Dev 4:54-66. https://doi.org/10.1016/j.wrr.2014.09.002

81. Singer J, Pham HT, Hoang H (2014) Broadening stakeholder participation to improve outcomes for dam-forced resettlement in Vietnam. Water Resour Rural Dev 4:85-103. https://doi.org/10.1016/j.wrr.2014.07.001

82. Molle F, Foran T, Käkönen M (2012) Contested waterscapes in the mekong region: Hydropower, livelihoods and governance 1-426 p. doi:https://doi. org/10.4324/9781849770866

83. Rousseau JF, Orange D, Habich-Sobiegalla S, Van Thiet N (2017) Socialist hydropower governances compared: dams and resettlement as experienced by Dai and Thai societies from the Sino-Vietnamese borderlands. Reg Environ Chang 17(8):2409-2419. https://doi.org/10.1007/ s10113-017-1170-0

84. Chauhan M (2010) A perspective on watershed development in the Central Himalayan State of Uttarakhand, India. Int J Ecol Environ Sci 36(4):253-69. https://www.indiawaterportal.org/sites/indiawaterportal. org/files/A_perspective_of_watershed_development_in_the_central_ Himalayan_state_of_Uttarakhand_Himmotthan_IJEES_2010.pdf
85. Balasubramanya S, Giordano M, Wichelns D, Sherpa T (2014) Sharing hydropower revenues in Nepal, over time and across districts and regions. Water Resour Rural Dev 4:104-111. https://doi.org/10.1016/j.wrr. 2014.10.007

86. Sinclair AJ (2015) A comparative case study of small hydro development in the Indian himalaya. In: Spatial Diversity and Dynamics in Resources and Urban Development: Regional Resources 1: 361-78. doi:10.1007/978-94-017-9771-9

87. Biedenweg K, Hanein A, Nelson K, Stiles K, Wellman K, Horowitz J (2014) Developing Human Wellbeing Indicators in the Puget Sound: Focusing on the Watershed Scale. Coast Manag 42(4):374-390. https://doi.org/10. 1080/08920753.2014.923136

88. Melamed-Varela E, Blanco-Ariza AB, Rodríguez-Calderón G (2018) Creación de valor compartido: estado y contribuciones a la sostenibilidad corporativa. Mag Sch Bus Adm 85:37-56. https://doi.org/10.21158/01208 160.n85.2018.2047

\section{Publisher's Note}

Springer Nature remains neutral with regard to jurisdictional claims in published maps and institutional affiliations.
Ready to submit your research? Choose BMC and benefit from:

- fast, convenient online submission

- thorough peer review by experienced researchers in your field

- rapid publication on acceptance

- support for research data, including large and complex data types

- gold Open Access which fosters wider collaboration and increased citations

- maximum visibility for your research: over 100M website views per year

At BMC, research is always in progress.

Learn more biomedcentral.com/submissions 